\title{
Carbon emissions and economic assessment of farm operations under different tillage practices in organic rainfed almond orchards in semiarid Mediterranean conditions
}

\author{
Bernardo Martin-Gorriz $^{\mathrm{a}, *}$, José F. Maestre-Valero ${ }^{\mathrm{a}}$, María Almagro ${ }^{\mathrm{b}}$, Carolina Boix-Fayos ${ }^{\mathrm{b}}$, \\ María Martínez-Mena ${ }^{\mathrm{b}}$ \\ ${ }^{a}$ Escuela Técnica Superior de Ingeniería Agronómica, Universidad Politécnica de Cartagena. Paseo Alfonso XIII, 48. 30203 Cartagena, Spain \\ ${ }^{\mathrm{b}}$ Soil Erosion and Conservation Research Group, CEBAS-CSIC, Spanish Research Council, Campus de Espinardo 30100, P.O. Box 164, Murcia, Spain
}

\section{A R T I C L E I N F O}

\section{Keywords:}

Carbon footprint

Reduced tillage

Green manure

Farm profitability

Climate change mitigation

Rainfed agriculture

\begin{abstract}
A B S T R A C T
Sustainable land management practices, such as reduced tillage or crop diversification, are potentially efficient measures to fight against soil degradation and desertification. The decision to approve these practices must be justified by both integrated environmental and economic assessment studies. In this work, we analysed the carbon emissions associated to farm operations and economic profitability for two organic rainfed almond (Prunus dulcis Mill.) farms under semiarid conditions. In the analysis, we considered the following soil management strategies: conventional tillage (CT); reduced tillage (RT); reduced tillage plus green manure (RTG); and no tillage (NT). A cradle-to-farm gate life cycle assessment (LCA) was applied based on long-term data from two farms. The results obtained showed that the NT strategy provided, as expected, the lowest greenhouse gas (GHG) emissions but that its yield was also the lowest, which negatively affects its economic viability even with the consideration of subsidies. The RT strategy reduced GHG emissions and improved the ratio of profit/GHG emissions, whilst the RTG strategy increased GHG emissions and reduced the ratio of profit/GHG emissions as a consequence of using seeds. In conclusion, it has been demonstrated that some level of reduced tillage leads to environmental and economic benefits with respect to conventional tillage in organic rainfed almond orchards under semiarid conditions.
\end{abstract}

\section{Introduction}

Almond is the major rainfed woody crop in Spain, covering 686,576 ha; i.e. $85 \%$ of the rainfed woody surface area. It is mostly concentrated in Mediterranean areas such as the Region of Murcia, where it accounts for $98 \%$ of the rainfed woody surface area (ESYRCE, 2018).

It has been traditionally considered as a marginal crop, and as such, has been located on poor lands where other crops cannot be established. In the Region of Murcia, almond rainfed orchards have been characterised by low density plantations (200 trees/ha); weed control by frequent tillage, which also favours the water reposition in the soil profile; and limitation of the tree size by pruning (Ramos et al., 2009; Martínez-Mena et al., 2013). However, conventional tillage also involves negative aspects such as high-water losses by direct soil evaporation, destruction of the soil structure, high organic matter and nutrient losses and high erosion rates (Gómez et al., 2009; Martínez-
Mena et al., 2008). Accordingly, rainfed almond orchards usually have low yields (about 350-400 kg of almond kernel per hectare; Arquero, 2013).

In this context, the application of sustainable management practices such as reduced tillage or the introduction of green manure has attracted increased interest. According to UNEP-UNDP-UNCCD (2008), such practices are basic tools to combat desertification, soil degradation and reduction of the structural stability, the organic carbon content and the microbial activity.

The benefits associated to reduced tillage are a reduction in soil erosion, leaching and runoff of agricultural chemicals and carbon emissions; the improvement of soil structure; and the increase in soil organic carbon sequestration (Aguilera et al., 2013; Alvaro-Fuentes et al., 2009; Arah et al., 1991; Aulakh et al., 1984; Holland, 2004; Towery, 1998; Uri et al., 1998). Despite these positive on-site effects on the ecosystem services due to the implementation of sustainable management practices in almond agriculture areas, the off-site effects of

\footnotetext{
* Corresponding author.

E-mail address: b.martin@upct.es (B. Martin-Gorriz).
} 
those practices on other ecosystem services have also been highlighted. These latter effects include soil erosion control, water availability and flood regulation at catchment scale (Eekhout and de Vente, 2019).

However, few studies have assessed the effect of energy consumption and carbon emissions associated to farm operations, and most that have done so focused mainly on the effects of conservation tillage in herbaceous crops (Clements et al., 1995; Guardia et al., 2016; West and Marland, 2002; Zaher et al., 2013).

Concerning the economic evaluation of rainfed almond orchards, herbaceous crop agro-systems with reduced tillage are more profitable in moderate and high rainfall zones but are less profitable in low rainfall zones (Zaher et al., 2013). Even though several studies have shown that energy and production cost savings may be achieved through reduced tillage systems compared with conventional tillage (Hernánz et al., 1995; Holland, 2004), many producers in some European countries are reluctant to adopt such a practice as it may have contrasting consequences for crop yields, depending on the annual climatic conditions (Van den Putte et al., 2010). In this context, the common agricultural policy has put various instruments into place to promote a sustainable use of soil, including rural development programmes and greening measures (EC, 2019). Organic agriculture is one such practice included in the rural development programmes. Exceptionally, organic agriculture of almond orchards is becoming a common practice in southeast Spain, incentivised by agricultural subsidies and promoted by the low economic benefits of rainfed almond production (MAGRAMA, 2015). Indeed, around 63\% of the almond production in the Region of Murcia is under organic agriculture (CAERM (Consejo de Agricultura Ecológica de Murcia), 2019). However, organic agriculture is not always accompanied by other conservation management practices such as reduced tillage intensity, or the use of cover crops including leguminous species (Almagro et al., 2016). It is therefore necessary to make widespread the environmental and economic benefits of sustainable management practices to achieve environmentally sustainable organic almond production.

The main goal of this study is to carry out an integrated environmental (focused on the $\mathrm{CO}_{2}$ emissions) and economic assessment of farm operations under different tillage practices in organic rainfed almond orchards under semiarid Mediterranean conditions.

\section{Materials and methods}

\subsection{Sites description}

Two organic rainfed almond (Prunus dulcis Mill.) orchards located in the northwest (Cehegín, $38^{\circ} 3^{\prime} 15^{\prime \prime} \mathrm{N}, 1^{\circ} 46^{\prime} 12^{\prime \prime} \mathrm{W}$; $633 \mathrm{~m}$ a.s.l., hereafter "Farm A") and centre (Zarzadilla de Totana, 37 $51^{\prime} 59^{\prime \prime} \mathrm{N}, 1^{\circ} 43^{\prime} 11^{\prime \prime} \mathrm{W}$; $839 \mathrm{~m}$ a.s.l., hereafter "Farm B") of the Region of Murcia, in southeastern Spain, were selected for the carbon emission analysis and economic assessment (Fig. 1). This study was carried out at two 14-yearold commercial almond orchards, cv Ferranges in farm A and cv Desmayo in farm $B$. The trees were spaced at $7 \mathrm{~m} \times 7 \mathrm{~m}$ for both farms. Both sites were located on relatively shallow soils (average soil depth about 30 and $45 \mathrm{~cm}$ at farms $\mathrm{A}$ and $\mathrm{B}$, respectively) with moderate southeast-facing slopes of around 7\% (farm A) and east-facing slopes ranging from $5 \%$ to $15 \%$ (farm B). Further information on the experimental plots is available in Almagro et al. $(2016,2017)$ and MartínezMena et al. (2013).

\subsection{Strategies and input data}

The studied strategies were based on four different soil tillage approaches: (i) conventional tillage (CT; designed as the control strategy), (ii) reduced tillage (RT), reduced tillage combined with green manure (RTG), and no-tillage (NT). Tables 1 and 2 show, for each scenario, the farm operations considered in farms A and B, respectively.

In farm $\mathrm{A}$, these conservation practices were carried out for ten consecutive years, between 2009 and 2018; whereas in farm B, they were conducted for seven consecutive years, between 2009 and 2015. No fertilisers or pesticides (organic almonds) were applied during the study period. As systems inputs, almond kernel yield and pruned woody biomass were collected annually (Table 3). Differences in yield between plots were mainly attributed to significant differences in: (1) tree size: although in both farms the trees had the same age, the average value of trunk perimeter in farm B was about two thirds lower than that in farm A $(13.6 \pm 0.02 \mathrm{~cm}$ vs $50.07 \pm 5.56 \mathrm{~cm})$; (2) different almond varieties; (3) annual rainfall: during the trial period the average annual rainfall in farm B $(261.3 \pm 111.4 \mathrm{~mm})$ was lower than in farm A (340.11 $\pm 30.9 \mathrm{~mm}$, SIAM, 2019); and (4) the slope of the land: it was much higher in farm B than in farm A, which leads to significantly greater losses of nutrients by erosion in the former (Martínez-Mena et al., 2019a).

\subsection{System boundaries}

The system boundaries are presented in Fig. 2. A cradle-to-gate approach was used. The system boundaries included all processes that took place in the field, from soil management to harvesting. The following four main field operations were considered for both experimental fields (Tables 1 and 2):

i) Soil management: tillage was performed mechanically with tractors and their respective implements (a disc harrow in farm $\mathrm{A}$ and a field cultivator in farm B) to control weeds. In the CT strategy, which is the most common soil management practice among farmers in this area, mechanical soil management was applied three times a year following important rainfall events. In the RT strategy, tillage operations were reduced to twice a year (autumn/spring). In the RTG strategy, tillage operations were also reduced to twice a year (in early autumn to bury the seeds applied manually and in May/June to bury the green manure residues) (Tables 1 and 2). The green manure consisted of a mix of common vetch (Vicia sativa L.) and common oat (Avena sativa L.) planted at a rate of $150 \mathrm{~kg}$ seeds/ha in a proportion of 3:1. In the NT strategy, the weeds are cut in May and left on the soil surface.

ii) Pruning and pick-up of pruned biomass: this was carried out manually with pruning shears, and the pruned woody biomass was collected using a tractor and a pick-up device, to be burned.

iii) Almond harvest: this was carried out using a tractor with a trunk shaker incorporated. This task was performed by external dealers (services) in both farms, using a high-powered tractor not available on the farms.

iv) Transport in-shell almonds (field to farm gate): harvested almonds were transported, on average, a one-way distance of $5 \mathrm{~km}$ in a farm trailer.

In short, for all these field operations, the manufactured machinery used for the orchards, the diesel fuel used by the tractors, and the production of seeds for sowing in the RTG strategy were considered.

The assessment did not include: (i) the nursery stage of almond trees, mainly due to the lack of reliable data regarding this phase; (ii) the disposal of material or waste; (iii) the manufacture and construction of a shed for farm machinery storage and a plot fence; and (iv) the soil and biomass carbon sequestration rate in rainfed almond orchards.

\subsection{Functional units}

In this study, two functional units (FU) were used; i.e. (a) 1 hectare (ha) of almond orchard, and (b) 1 kilogram ( $\mathrm{kg}$ ) of raw brown-skin almond (almond kernel). We selected these two because of the substantial variations in the environmental footprint when comparing crops per unit of area and per product unit (Tuomisto et al., 2012).

\subsection{Calculation of greenhouse gas emissions}

Greenhouse gas (GHG) emissions were estimated following the IPCC 


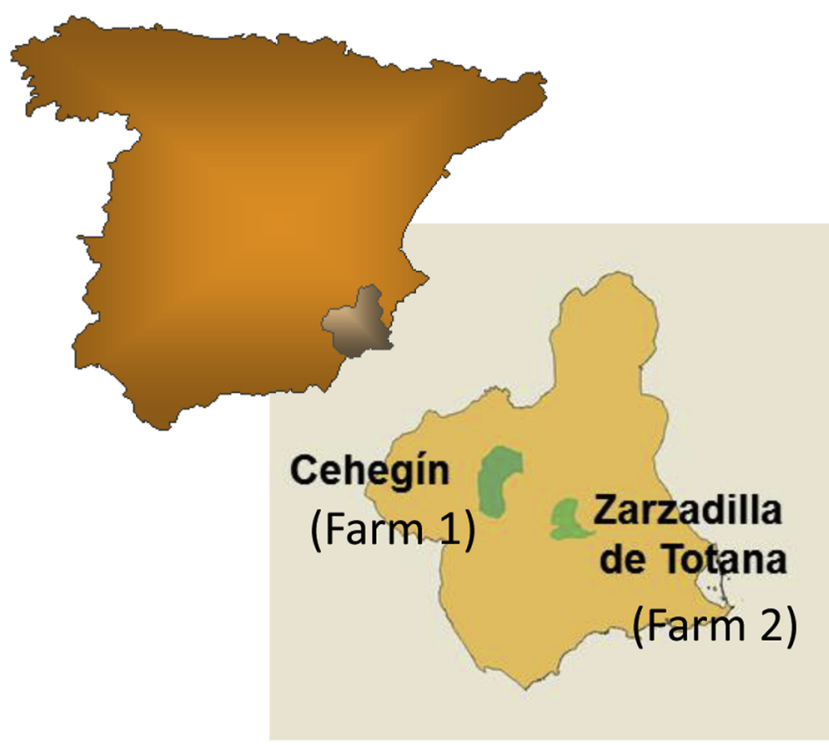

A
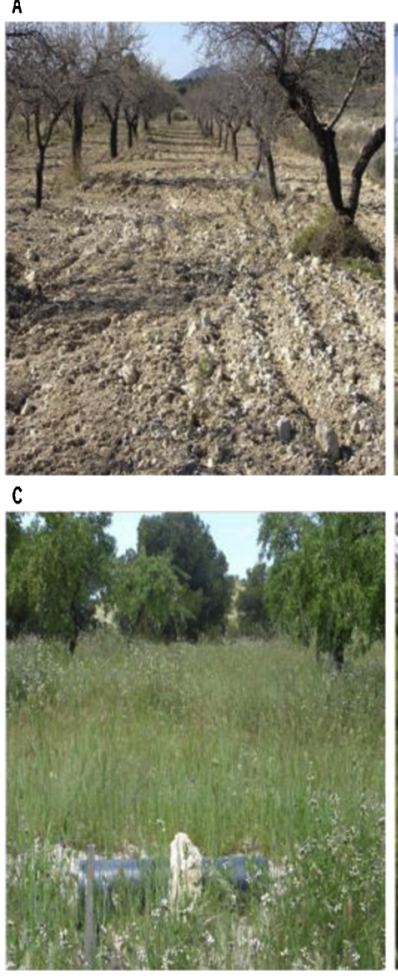
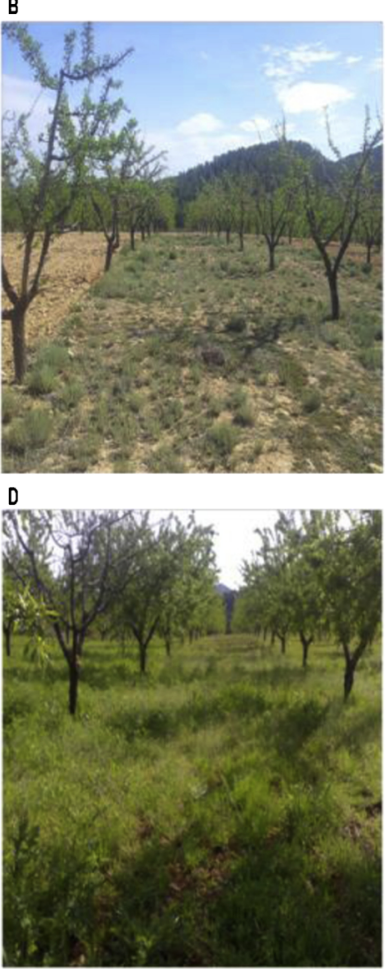

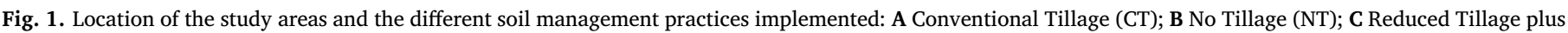

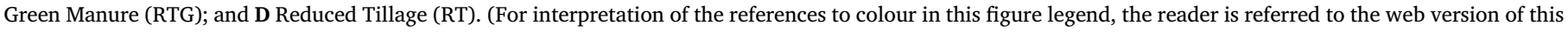
article).

$2013 \mathrm{v} 1.03$ (time frame of 100 years) methodology from the Intergovernmental Panel on Climate Change (IPCC, 2006) by quantifying the total GHG emissions directly or indirectly caused by, or accumulated during, the cultivation of 1 ha of almond orchards. GHG emissions were reported in units of carbon dioxide equivalent $\left(\mathrm{CO}_{2}\right.$ eq $)$ based on the most recent IPCC factors (Myhre et al., 2013). The life cycle impact analysis was performed using the commercial Simapro 8.5.2 (Pre Consultants, 2019) software, by taking into account the phases of classification and characterisation defined by the standards of ISO 14040-14044 series (ISO, 2006).

The following four inputs were considered in order to calculate the GHG emissions:

i) Manufacture of agricultural machinery: farm machinery releases GHG emissions through its manufacturing and by burning fossil fuels during field operations. The LCA inventories for the manufacture of agricultural machinery are specific to the various types of machinery (tractors, tillage implements or other implements). The amount of machinery (AM) used for a specific agricultural operation was calculated by multiplying the mass (MA) of that machinery by the operation time (OT) and dividing the result by the lifetime of the machinery (LT) (Nemecek et al., 2000):

AM $(\mathrm{kg} / \mathrm{FU})=\mathrm{MA}(\mathrm{kg}) \times$ OT $(\mathrm{h} / \mathrm{FU}) / \mathrm{LT}(\mathrm{h})$ [Eq.1]

where FU (see Section 2.4) is the functional unit of the LCA. The lifetime of the machinery considered for these case studies was a Spanish average for each type of machinery (Márquez, 2004). The machinery used in farms A and B for each tillage strategy are shown in Tables 1 and 2.

ii) Production, transportation and combustion of diesel fuel: the diesel consumption used by the agricultural machinery was estimated for each field operation according to Márquez (2004), who presented diesel consumption of specific machinery for woody crops. The inventories for the extraction and transportation of crude oil, its transformation into diesel, its distribution, and diesel exhaust emissions were taken from the Ecoinvent database v 3.5. iii) Seed production: the emissions involved in seed production were taken from the Ecoinvent database v.3.5. according to common vetch (Vicia sativa L.) and common oat (Avena sativa L.) at the proportion of $3: 1$.

\subsection{Carbon footprint calculation}

The carbon footprint (CF) expresses the total GHGs emitted by direct or indirect effects by a product. In this study, the $\mathrm{CO}_{2}$ emissions per $\mathrm{kg}$ of almond kernel produced $\left(\mathrm{kg} \mathrm{CO} \mathrm{CO}_{2}\right.$ eq $/ \mathrm{kg}$ almond kernel) were calculated as the ratio between the total GHG emissions $\left(\mathrm{kg} \mathrm{CO}_{2}\right.$ eq $\left./ \mathrm{ha}\right)$ and the yield ( $\mathrm{kg}$ almond kernel/ha).

Since the functional unit used to express CF is a mass unit, it was important to document the mass yields ( $\mathrm{kg} / \mathrm{ha}$ ) of almond kernel used (Table 3).

\subsection{Economic assessment}

An economic analysis, based on the inventoried data presented in Tables 1 and 2, was also performed to compare the profitability of the two dryland areas; farms A and B. Data were converted into economic information, inputting the prices presented in Table 4. Detailed hourly cost calculations of field operations can be found in the Supplementary material (Table 1S). The economic valuations were obtained from interviews to several agricultural stakeholders, extension service and market operators. The economic result was calculated as the difference between the total output (TO) and the operational costs (OC). TO was the revenue from sales of almond kernel valued according to the official prices published by the Government of the Region of Murcia (CARM, 2019); i.e. a price for organic almonds kernel cv Ferragnes $7.92 \pm 1.4$ $€ / \mathrm{kg}$, and cv. Desmayo $8.47 \pm 1.51 € / \mathrm{kg}$ calculated as the average of all the origin prices between 2012-2018 (CARM, 2019). The price of organic almonds was around $2 € / \mathrm{kg}$ higher than conventional almonds. In addition, organic producers benefit from agri-environment subsidies. 

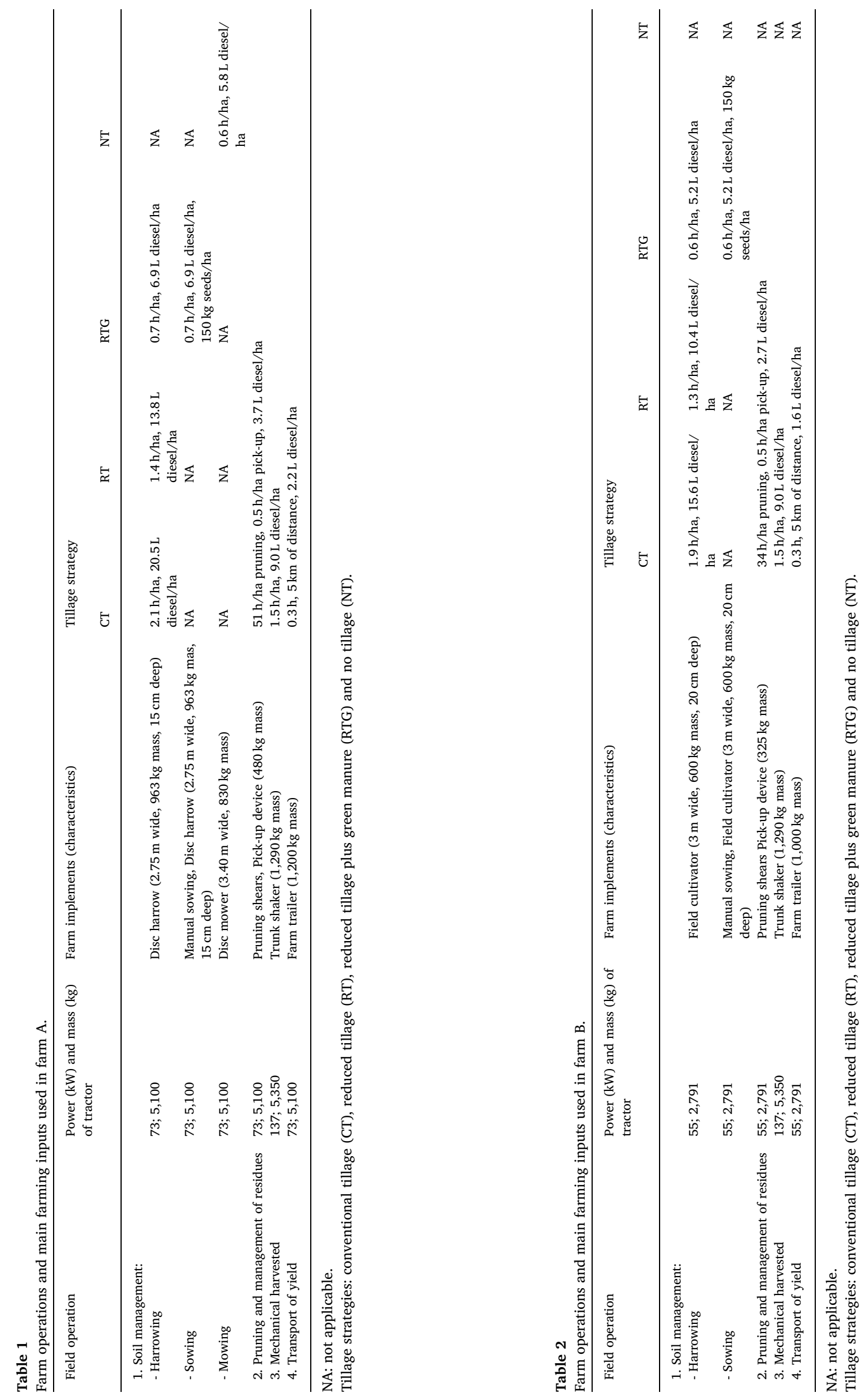
Table 3

Almond yield (kg kernel/ha/year) and pruned biomass by tillage strategy at the two farms.

\begin{tabular}{|c|c|c|c|c|c|}
\hline \multirow[t]{2}{*}{ Item } & \multirow[t]{2}{*}{ Place } & \multicolumn{4}{|l|}{ Tillage strategy } \\
\hline & & $\mathrm{CT}$ & RT & RTG & NT \\
\hline Yield (kg kernel/ha-year) & $\begin{array}{l}\text { Farm A } \\
\text { Farm B }{ }^{2}\end{array}$ & $\begin{array}{l}321 \pm 165 b^{3} \\
40 \pm 37 a\end{array}$ & $\begin{array}{l}311 \pm 178 b \\
61 \pm 77 a\end{array}$ & $\begin{array}{l}269 \pm 160 b \\
31 \pm 34 a\end{array}$ & $\begin{array}{l}87 \pm 66 \mathrm{a} \\
*\end{array}$ \\
\hline Pruned biomass (Mg/ha-year) & $\begin{array}{l}\text { Farm A } \\
\text { Farm B }\end{array}$ & $\begin{array}{l}2.10 \pm 2.56 a^{4} \\
0.71 \pm 0.41^{4}\end{array}$ & $3.60 \pm 4.59 \mathrm{a}$ & $1.87 \pm 2.14 \mathrm{a}$ & $0.60 \pm 0.20 \mathrm{a}$ \\
\hline
\end{tabular}

*: In farm B, no tillage strategy was carried out.

1: average of 10-year period (2009-2018).

2: average of 7-year period (2009-2015).

3: Martínez-Mena et al. (2019b) (Farm A) and personal communication (Farm B).

4: calculated following Velázquez-Martí et al. (2011).

Tillage strategies: conventional tillage (CT), reduced tillage (RT), reduced tillage plus green manure (RTG) and no tillage (NT).

In each farm, production systems with different letters had significant differences according to Fisher (LSD) at 95.0\%.

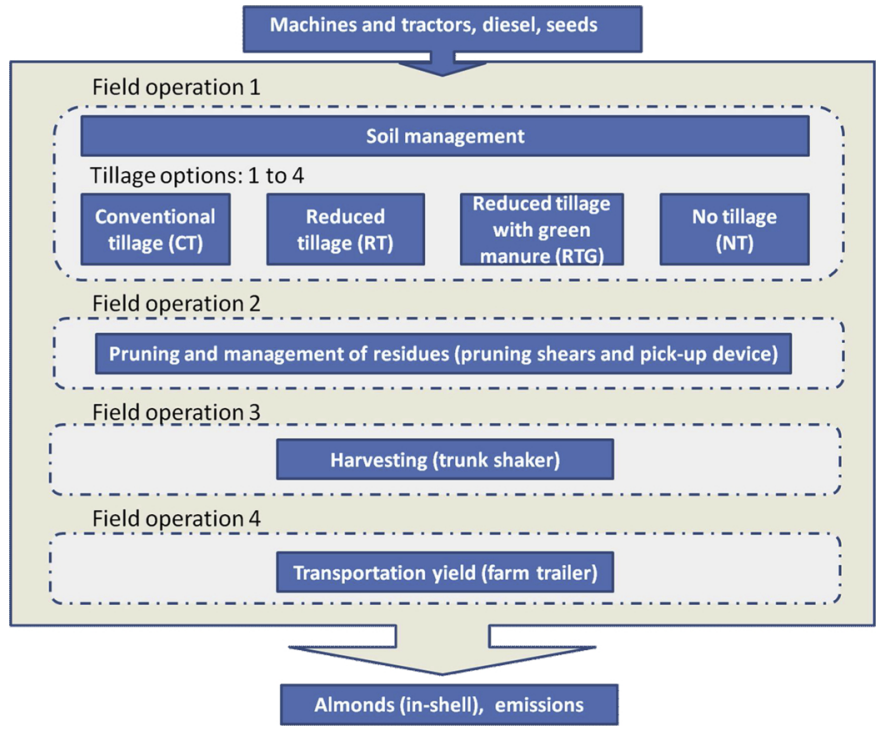

Fig. 2. Field operations considered within the system boundaries for the tillage strategies analysed.

The European Union recognises the role of organic farming as an asset for both the land and for consumers. Under the common agricultural policy for the period 2014-2020, organic farmers can benefit from several support measures. Organic almond producers in the Region of Murcia receive a grant of $240 €$ /ha-year from the European Union devoted to organic agriculture maintenance (BORM, 2015).

Machinery costs, manpower and seeds (in the RTG strategy) were calculated as follows: machinery costs were calculated according to Miserque et al. (1997) and Márquez (2004). The following variables were used (Table 4 and Table $1 \mathrm{~S}$ of the supplementary material): (a) purchase price for tractors and implements; (b) depreciation estimated by working life (years) and annual usage (h); (c) interest rate, $5 \%$ of purchase price; (d) taxes, insurance and housing, $2 \%$ of purchase price; (e) cumulative repair and maintenance costs estimated by working time; (f) diesel consumption for farm operation $(\mathrm{L} / \mathrm{h})$ and diesel price of $1 € / \mathrm{L}$; and $(\mathrm{g})$ manpower $9.92 € / \mathrm{h}$ for trained workers (drivers and pruner workers) and $8.72 € / \mathrm{h}$ for labourers.

\section{Results}

\subsection{Greenhouse gas emissions}

Different results were obtained for the same strategy in each farm. Overall, the GHG emissions in farm A were higher than those in farm B (Table 5). This was mainly due to the lower power and mass of the tractors and implements in farm B; using smaller tractors means lower fuel consumption and GHG emissions. Total GHG emissions in CT were 134 and $106 \mathrm{~kg} \mathrm{CO}_{2 \mathrm{eq}}$ /ha in farms A and B, respectively (Table 5). GHG emissions in the RT strategy were lower than in CT (19\% in both farms). The main cause of these reductions was the reduction of one tillage labour per year (Tables 1 and 2). As expected, the NT strategy, with zero tillage, showed the lowest GHG emissions with reductions of $33 \%$ in farm A. Note that in farm B, the NT strategy was not implemented. In contrast, the highest GHG emissions were observed in the RTG strategy, despite the reduction of tillage. In this latter strategy, GHG emissions increased $41 \%$ in farm A and $57 \%$ in farm B compared to CT (Table 5). This was due to the seed production processes that were used as green manure in the RTG strategy and emitted $80 \mathrm{~kg} \mathrm{CO}_{2}$ eq per $150 \mathrm{~kg}$ seeds; the figure corresponds to 25 (oat) and 55 (vetch) $\mathrm{kg} \mathrm{CO}_{2}$ eq.

The emissions from the production, transportation and combustion of diesel ranged, irrespective of the experimental farm, between $42 \%$ in the RTG strategies to about $76 \%$ in the CT, RT and NT strategies and were the main component of the total GHG emissions (Table 5). Within these emissions, soil management showed the highest GHG emissions. It should be noted that mowing is the labour used in the NT strategy to control weeds, which represents $28.1 \%$. Mechanical harvesting was the second cause of GHG emissions. In farm A, mechanical harvesting

Table 4

Cost of field operations and inputs by farm.

\begin{tabular}{|c|c|c|c|c|c|c|c|c|}
\hline Farm & Tractor & Tillage implement & Manual sowing & Disc mower & Manual pruning & Pick-up device & Trunk shaker & Farm trailer \\
\hline \multicolumn{9}{|l|}{ Farm A } \\
\hline - Machinery (€/h) & $21.28^{\mathrm{a}}$ & $19.78^{\mathrm{b}}$ & & 13.96 & & 13.07 & 60 & 15.95 \\
\hline - Labour $(€ / h)$ & 9.92 & & 8.72 & & 9.92 & & & \\
\hline - Seeds $(€ / \mathrm{kg})$ & & & 0.5 & & & & & \\
\hline \multicolumn{9}{|l|}{ Farm B } \\
\hline - Machinery $(€ / h)$ & $18.44^{\mathrm{c}}$ & $16.93^{\mathrm{d}}$ & & & & 11.25 & 60 & 14.12 \\
\hline - Labour $(€ / h)$ & 9.92 & & 8.72 & & 9.92 & & & \\
\hline - Seeds $(€ / \mathrm{kg})$ & & & 0.5 & & & & & \\
\hline
\end{tabular}

a: tractor $73 \mathrm{~kW}$, b: disc harrow, c: tractor $55 \mathrm{~kW}$, d: field cultivator. 
Table 5

GHG emissions ( $\mathrm{kg} \mathrm{CO}_{2}$ eq/ha) associated with inputs for tillage strategy at the farms.

\begin{tabular}{|c|c|c|c|c|c|c|c|}
\hline \multirow[t]{2}{*}{ Input / field operation } & \multicolumn{4}{|c|}{ Farm A. Tillage strategy } & \multicolumn{3}{|c|}{ Farm B. Tillage strategy } \\
\hline & CT & RT & RTG & NT & CT & RT & RTG \\
\hline 1. Emissions from production, transportation and combustion of diesel & $105(78.7)$ & $84(76.6)$ & $84(44.3)$ & $69(76.3)$ & $84(79.1)$ & $66(76.3)$ & $66(39.6)$ \\
\hline - Soil management & $62(46.1)$ & $40(36.6)$ & $40(21.2)$ & $25(28.1)$ & 47 (44.7) & $29(33.9)$ & $29(16.0)$ \\
\hline - Pruning and management of residues & $11(8.1)$ & $11(9.9)$ & $11(5.8)$ & $11(12.1)$ & $7(6.9)$ & $7(8.5)$ & $7(3.9)$ \\
\hline - Mechanical harvester & $25(19.0)$ & $25(23.3)$ & $25(13.5)$ & $25(28.0)$ & $25(24.1)$ & $25(29.7)$ & $25(13.7)$ \\
\hline - Transport of yield & $7(5.4)$ & $7(6.7)$ & $7(3.9)$ & $7(8.1)$ & $4(3.4)$ & $4(4.2)$ & $4(2.0)$ \\
\hline 2. Emissions from manufacture of agricultural machinery & $29(21.3)$ & $25(23.5)$ & 25 (13.5) & $21(23.7)$ & $22(20.9)$ & $20(23.7)$ & $20(12.2)$ \\
\hline - Soil management & $9(6.2)$ & $6(5.2)$ & $6(3.0)$ & $1(1.1)$ & $5(4.4)$ & $3(3.6)$ & $3(0.6)$ \\
\hline - Pruning and management of residues & $2(2.1)$ & $2(1.9)$ & $2(1.1)$ & $2(2.3)$ & $1(1.0)$ & $1(1.2)$ & $1(4.9)$ \\
\hline - Mechanical harvester & $8(6.0)$ & $8(7.3)$ & $8(4.3)$ & $8(9.0)$ & $8(7.7)$ & $8(9.5)$ & $8(4.9)$ \\
\hline - Transport of yield & $10(7.5)$ & $10(9.1)$ & $10(5.3)$ & $10(11.3)$ & $8(7.7)$ & $8(9.5)$ & $8(4.9)$ \\
\hline 3. Emissions of seed production & NA & NA & $80(42.2)$ & NA & NA & NA & $80(48.2)$ \\
\hline Total emissions $(1+2+3)$ & 134 & 109 & 189 & 90 & 106 & 86 & 166 \\
\hline
\end{tabular}

Tillage strategies: conventional tillage (CT), reduced tillage (RT), reduced tillage plus green manure (RTG) and no tillage (NT).

The number in parentheses indicates a percentage of each crop total GHG emissions.

NA: not applicable.

ranged from $13.5 \%$ in RTG to $28.1 \%$ in NT. In farm B, it ranged from $13.7 \%$ in RTG to $29.7 \%$ in RT; $25 \mathrm{~kg} \mathrm{CO}_{2}$ eq $/$ ha in both farms.

\subsection{Carbon footprint}

While analysing the carbon emissions per $\mathrm{kg}$ of almond kernel, farm A was four-fold lower than farm B (3.14 vs $0.63 \mathrm{CO}_{2}$ eq $/ \mathrm{kg}$ almond kernel, on average; Table 6). The foremost cause for this difference was attributed to the low yield in farm B. On the other hand, analysing by tillage strategy, reduced tillage in farm A showed a slight effect on the $\mathrm{CF}$; however, RTG and NT increased CF. The mainly reason for this result in the RTG strategy was the increase in GHG emissions due to the use of seeds; however, in NT it was the reduction of GHG emissions and also the yield; i.e. the substitution of tillage labour by mowing in the NT strategy which reduced the GHG emissions from 134 to $90 \mathrm{~kg} \mathrm{CO}_{2}$ eq $/$ ha in farm A (reduction of 33\%; Table 5) and the yield from 321 to $87 \mathrm{~kg}$ kernel/ha-year (reduction of 73\%). Consequently, the $\mathrm{kg} \mathrm{CO} 2 \mathrm{eq} / \mathrm{kg}$ almond kernel reached 1.03 in the NT strategy. This supposes an increase of $148 \%$ with respect to the CT strategy. In farm B, despite following the same methodology, the results are somewhat distorted by the high variability in yield among the strategies (Table 3 ).

\subsection{Economic assessment}

Table 7 shows the operational costs, revenues, and profits for farms $\mathrm{A}$ and $\mathrm{B}$ considering the different experimental treatments.

In both farms, the RT and NT (not analysed in farm B) strategies reduced the operational costs by $4 \%$ and $10 \%$, respectively. On the contrary, the RTG strategy, which considered seed acquisition and the manual sowing, increased the cost by $7 \%-10 \%$ compared to the CT treatment, in farms A and B, respectively.

In farm $\mathrm{A}$, the highest revenue was observed in the CT treatment

Table 6

Carbon footprint ( $\mathrm{kg} \mathrm{CO}_{2} \mathrm{eq} / \mathrm{kg}$ almond kernel) by tillage strategy and farm.

\begin{tabular}{|c|c|c|c|c|}
\hline \multirow[t]{2}{*}{ Place } & \multicolumn{4}{|c|}{ Tillage strategy } \\
\hline & СТ & RT & RTG & NT \\
\hline Farm $A^{1}$ & 0.42 & 0.35 & 0.70 & 1.03 \\
\hline Farm $B^{2}$ & 2.65 & 1.41 & 5.35 & * \\
\hline
\end{tabular}

*: In farm B, no tillage strategy was carried out.

1: average of 10-year period (2009-2018).

2: average of 7-year period (2009-2015).

Tillage strategies: conventional tillage (CT), reduced tillage (RT), reduced til-

lage plus green manure (RTG) and no tillage (NT).
$(2,781.17 € / \mathrm{ha})$, whereas the lowest was obtained in the NT treatment (854.95€/ha). In this latter case, if the subsidy to organic farming is not considered, it even led to a negative profit of $-30.69 € /$ ha. Considering the economic and environmental analysis together, RT was the best strategy with the highest ratio of profit/GHG emissions $\left(18.78 € / \mathrm{kgCO}_{2}\right.$ eq).

In farm B, the highest revenue was observed in the RT strategy due to the higher yield compared to the CT treatment. In that farm, if the subsidy to organic farming is not considered, it even led to negative profits in the CT (-187.62 €/ha) and in RTG (-321.99 €/ha) strategies. Considering the economic and environmental analysis together, RT was again the best strategy with the highest ratio of profit/GHG emissions $\left(3.04 € / \mathrm{kgCO}_{2}\right.$ eq). Comparing between farms, the RT strategy in farm A reported a six-fold higher ratio of profit/GHG emissions than in farm B.

\section{Discussion}

The GHG emissions estimated in this work were much lower than the emissions given by other authors in almond crops. For example, in the USA, GHG emissions ranged from 3,200 to $6,842 \mathrm{kgCO}_{2}$ eq $/$ ha (Marvinney et al., 2015; Venkat, 2012) and in Spain GHG emissions ranged from 1,269 (organic) to 1,531 (no organic) $\mathrm{kgCO}_{2}$ eq/ha (Aguilera et al., 2015). The main cause for those high GHG emissions, as compared to our study, was the heavy use of pesticides, irrigation and above all fertilisers in the case of non-organic farms. In fact, $\mathrm{N}$ fertiliser production and application was the dominant cause of GHG emissions in all the studies in conventional farms; i.e. 31\% (Venkat, 2012) to $40 \%$ (Aguilera et al., 2015) share of GHG emissions. However, in organic farms, diesel was the main contributor to GHG emissions (63\% in the case of Aguilera et al., 2015). In our study, those emissions from diesel amounted to around $80 \%$ of the GHG emissions, because tillage was the only field operation in the CT strategy (Table 5).

Overall, the use of inputs in irrigated woody orchards is much higher than in rainfed woody orchards. For example, regarding GHG emissions related to machinery use (machinery and diesel consumption) in organic almonds production, Aguilera et al. (2015) reported seven-fold higher GHG emissions than in our study. It should be noted that in said study, machinery was also used for other field operations such as the application of pesticides. In another study, Garcia et al. (2004) reported four phytosanitary treatments per year in irrigated almond orchards.

Several ways to minimize the GHG emissions from diesel consumption which ought to be mentioned here have been identified:

(1) employ biodiesel from waste vegetable oil when possible. It should be noted that $\mathrm{CO}_{2 \mathrm{eq}}$ emissions from diesel are $74.3 \mathrm{gCO}_{2}$ eq $/ \mathrm{MJ}$ 
Table 7

Operational costs, revenues, and profits for farms A and B considering the different experimental treatments. It also presents the ratio profit/GHG emissions.

\begin{tabular}{|c|c|c|c|c|c|c|c|c|}
\hline \multirow[t]{2}{*}{ Field operation } & & \multicolumn{4}{|c|}{ Farm A. Tillage strategy } & \multicolumn{3}{|c|}{ Farm B. Tillage strategy } \\
\hline & & CT & RT & RTG & NT & CT & RT & RTG \\
\hline Operational cost $(€ /$ ha) & & 709.51 & 681.07 & 764.90 & 645.64 & 520.22 & 497.45 & 581.16 \\
\hline \multirow[t]{5}{*}{ 1.1. Soil management } & Harrowing & 85.01 & 56.57 & 28.34 & & 68.32 & 45.55 & 22.77 \\
\hline & Harrowing & & & 28.34 & & & & 22.77 \\
\hline & Manual sowing & & & 8.72 & & & & 8.72 \\
\hline & Seeds & & & 75.00 & & & & 75.00 \\
\hline & Mowing & & & & 21.14 & & & \\
\hline \multirow[t]{2}{*}{ 1.2. Pruning and management of residues } & Hand pruning & 505.92 & 505.92 & 505.92 & 505.92 & 337.28 & 337.28 & 337.28 \\
\hline & Pick-up & 17.41 & 17.41 & 17.41 & 17.41 & 14.85 & 14.85 & 14.85 \\
\hline 1.3. Mechanical harvested & Trunk shaker & 90 & 90 & 90 & 90 & 90 & 90 & 90 \\
\hline 1.4. Transport of yield & Farm trailer & 11.17 & 11.17 & 11.17 & 11.17 & 9.77 & 9.77 & 9.77 \\
\hline 2. Revenue ${ }^{\mathrm{a}}(€ / \mathrm{ha})$ & & $2,781.17$ & $2,728.61$ & $2,421.61$ & 854.95 & 572.60 & 758.34 & 499.17 \\
\hline 2.1. Sale of almond & & $2,541.17$ & $2,488.61$ & $2,181.61$ & 614.95 & 332.60 & 518.34 & 259.17 \\
\hline 2.2. Subsidy to organic farming & & 240 & 240 & 240 & 240 & 240 & 240 & 240 \\
\hline 3. Profit ${ }^{\mathrm{a}}(€ / \mathrm{ha})$ & & $2,071.66$ & $2,047.54$ & $1,656.71$ & 209.31 & 52.38 & 260.89 & -81.99 \\
\hline 3.1. Without considering 2.2 & & $1,831.66$ & $1,807.54$ & $1,416.71$ & -30.69 & -187.62 & 20.89 & -321.99 \\
\hline 3.2. Considering 2.2 & & $2,071.66$ & $2,047.54$ & $1,656.71$ & 209.31 & 52.38 & 260.89 & -81.99 \\
\hline 4. Ratio Profit/GHG emissions $\left(€ / \mathrm{kgCO}_{2 \mathrm{eq}}\right)$ & & 15.46 & 18.78 & 8.77 & 3.31 & 0.49 & 3.04 & -0.49 \\
\hline
\end{tabular}

Tillage strategies: conventional tillage (CT), reduced tillage (RT), reduced tillage plus green manure (RTG) and no tillage (NT).

a Revenue and profit have been shown considering the subsidy to organic farming.

(IPCC, 2006), whereas for biodiesel the figure is $14 \mathrm{gCO}_{2} \mathrm{eq} / \mathrm{MJ}$ (EPC (European Parliament and Council), 2009). As a result, this measure could cut the emissions by an average of between 56 (NT) and 77 (CT) $\mathrm{kg} \mathrm{CO} 2$ eq $/$ ha using biodiesel from waste vegetable oil; this would mean a decrease of $19 \%$ in GHG emissions by hectare.

(2) proper sizing of agricultural machinery in farm has been proposed by several authors (Page et al., 2011; Sastre et al., 2014). In our study, the use of diesel and the associated emissions per hectare could be lowered in farm A by using a smaller low-powered tractor (using $55 \mathrm{~kW}$ instead of $73 \mathrm{~kW}$ ); i.e. annual diesel consumption in farm A using $73 \mathrm{~kW}$ tractor was 35 (CT), 29 (RT or RTG) and 22 (NT) L/ha-year; however in farm B, using a $55 \mathrm{~kW}$ tractor it was 29 (CT) and 24 (RT or RTG) L/ha-year. Accordingly, tractor B saved around 17\% of diesel fuel by this strategy. From an economic point of view, it is also appealing given that it could save around $27 \%$ of the operational cost by year.

(3) the reduction of the tillage frequency in farm, as tillage reduction or suppression implies a decrease in $\mathrm{CO}_{2}$ emissions associated to farm operations, mainly driven by lower diesel consumption (Govaerts et al., 2009). In our study, the annual savings in diesel consumption using reduced-tillage strategies (RT and RTG) were 6.8 and $5.2 \mathrm{~L} / \mathrm{ha}$ year compared to CT, in farms A and B, respectively (Tables 1 and 2). Such reductions were equivalent to a reduction in $\mathrm{CO}_{2}$ emissions of 22 and $18 \mathrm{~kg} \mathrm{CO}_{2}$ eq/ha-year, in farms $\mathrm{A}$ and $\mathrm{B}$, respectively; In short, reducing one out of three tillages per year involved a reduction of $20 \%$ GHG emissions. We note that all our proposals detailed above can be compatible.

In terms of $\mathrm{kg} \mathrm{CO}_{2}$ eq $/ \mathrm{kg}$ almond kernel, in farm A we found much lower values for $\mathrm{CF}$ that those estimated by other authors who displayed values from 0.95 to $3.77 \mathrm{~kg} \mathrm{CO} 2$ eq $/ \mathrm{kg}$ almond kernel under irrigated almond orchards (Clune et al., 2017; Kendall et al., 2015; Marvinney et al., 2015; Nemecek et al., 2012). In those farms, intensive use of water, fertilisers and pesticides were given; this can explain the differences in $\mathrm{CF}$ with our farm where rainfed conditions and no fertilisation prevailed. Furthermore, the almond yield under irrigation is three- to four-fold higher than under rainfed almond orchards (Arquero et al., 2013; Calatrava et al., 2006).

On the other hand, the highest specific emission in farm B $(3.1 \mathrm{~kg}$ $\mathrm{CO}_{2}$ eq $/ \mathrm{kg}$ almond kernel, on average) compared to farm A can be explained by the extremely low productivity in that farm (Table 3 ).

Overall, there were important differences in yield between the farms (Table 3). The yield in farm A was much higher than in farm B; eightfold in CT, five-fold in RT and nine-fold in RTG. In farm A, significant differences were found between NT ( $87 \mathrm{~kg}$ almond kernel/ha) and the rest of the tillage strategies (CT, RT and RTG with an average of $300 \mathrm{~kg}$ almond kernel/ha). In farm B, the statistical analysis showed no significant differences among the tillage strategies (CT, RT and RTG) with an average of $44 \mathrm{~kg}$ almond kernel/ha (Table 3). Differences in yield between farms were explained in section 2.2.

Concerning the economic profitability (Table 7), farm B showed a negative mean profit (without subsidy), similar to that reported as the average value in the Region of Murcia (MAGRAMA, 2015); and closely matching those obtained by Calatrava et al. (2006) who conditioned the profit of rainfed almond producers in this region to EU subsidies. This demonstrates the powerful role that subsidies play on the configuration of agricultural and semi-natural landscapes, as established by other studies (van Leeuwen et al., 2019), with a very important influence on the soil conditions and economic viability.

On the other hand, farm A showed a positive profit without EU subsidies in all strategies except in the NT strategy. The economic benefits associated to RT compared to CT were very low, reporting a 4\% reduction in operational cost but $20 \%$ in GHG emissions. It should be noted that with reduced tillage in extensive crops this can reach up to 10\% (FAO, 2019).

The highest GHG emissions by farmer operations in RTG and also the lower profitability compared to CT or even RT should be taken with caution, given that: i) in this approximation other associated ecosystem services in the category of regulating (erosion control, flood control, pollination) and provisioning (green water availability, increase of biodiversity), as investigated by Almagro et al. (2016) have not been taken into account; and ii) an improvement in crop yields under RTG compared to CT has been observed after seven years from its implementation (Martínez-Mena et al., 2019b), which is not reflected in the average value of the ten years considered in this study (in the case of farm A). In order to promote the adoption of sustainable agricultural practices such as reduced tillage by farmers, it should be necessary to emphasise the environmental (GHG emissions reductions) rather than the economic benefits associated to it, and this requires support from public administrations through different strategies.

\section{Conclusions}

This study has determined carbon emissions and economically evaluated two organic rainfed almond agro-ecosystems considering different farm operations, including several tillage practices under 
semiarid Mediterranean conditions.

No tillage, as implemented in this study, provided the lowest GHG emissions, although this result must be taken with caution since yield was also significantly reduced and, even with subsidies, the strategy is very close to being economically unfeasible. The results hence suggest that some level of reduced tillage may provide certain environmental and economic benefits with respect to conventional tillage. Reducing one tillage pass per year; i.e. from three times to twice, has considerably reduced the GHG emissions and improved the ratio of profit/GHG emissions. However, reduced tillage combined with green manure has increased the GHG emissions from farm operations and reduced the ratio of profit/GHG emissions as a consequence of using seeds.

In short, under the conditions of this study and for the tested environmental and economic indicators, reduced tillage without green manure is the best strategy for almond producers and the sustainability of land. Nevertheless RTG could be become more positive in case other ecosystem services, in particular carbon sequestration, were considered.

Longer-term studies that integrate and quantify all the environmental benefits of these sustainable management practices would be necessary in order to obtain a more complete picture of their feasibility.

\section{Acknowledgements}

This study was supported by the European Commission H2020 (Grant 728003, DIVERFARMING Project), Fundación Séneca-Agencia de Ciencia y Tecnología de la Región de Murcia (Grant 08757/PI/08/ 19350/PI/14; DECADE Project Grant 20917/PI/18) and by the Agencia Estatal de Investigación (Grant CGL2014-55-405-R).

\section{Appendix A. Supplementary data}

Supplementary material related to this article can be found, in the online version, at doi:https://doi.org/10.1016/j.scienta.2019.108978.

\section{References}

Aguilera, E., Lassaletta, L., Gattinger, A., Gimeno, B.S., 2013. Managing soil carbon for climate change mitigation and adaptation in Mediterranean cropping systems. A meta-analysis. Agric. Ecosyst. Environ. 168, 25-36. https://doi.org/10.1016/j.agee. 2013.02.003.

Aguilera, E., Guzmán, G., Alonso, A., 2015. Greenhouse gas emissions from conventional and organic cropping systems in Spain. II. Fruit tree orchards. Agron. Sustain. Dev. 35, 725-737. https://doi.org/10.1007/s13593-014-0265-y.

Almagro, M., de Vente, J., Boix-Fayos, C., García-Franco, N., Melgares de Aguilar, J., González, D., Solé-Benet, A., Martínez-Mena, M., 2016. Sustainable land management practices as providers of several ecosystem services under rainfed Mediterranean agroecosystems. Mitig. Adapt. Strateg. Glob. Change 21, 1029-1043.

Almagro, M., Garcia-Franco, N., Martínez-Mena, M., 2017. The potential of reducing tillage frequency and incorporating plant residues as a strategy for climate change mitigation in semiarid Mediterranean agroecosystems. Agric. Ecosyst. Environ. 246, 210-220.

Alvaro-Fuentes, J., López, M.V., Arrúe, J.L., Moret, D., Paustian, K., 2009. Tillage and cropping effects on soil organic carbon in Mediterranean semiarid agroecosystems: testing the Century model. Agric. Ecosyst. Environ. 134, 211-217.

Arah, J.R.M., Smith, K.A., Crichton, I.J., Li, H.S., 1991. Nitrous oxide production and denitrification from Scottish arable soils. Soil Sci. 42, 351-367.

Arquero, O., 2013. Manual del Almendro. Consejería de Agricultura, Pesca y Desarrollo Rural, Sevilla.

Aulakh, M.S., Rennie, D.A., Paul, E.A., 1984. Gaseous N losses from soils under zero-till as compared to conventional-till management systems. J. Environ. Qual. 13, 130-136.

BORM, 2015. Orden de 25 de Mayo de 2015, de la Consejería de Agricultura y Agua, por la que se establecen, en la Región de Murcia, las Bases Reguladoras de determinadas líneas de ayuda correspondientes a la medida 10 "Agroambiente y Clima" y Medida 11 "Agricultura Ecológica" del Programa de Desarrollo Rural de la Región de Murcia 2014-2020, y se aprueba la convocatoria correspondiente al año 2015 de las citadas líneas de ayuda, BORM, 120. pp. 21957-22062.

CAERM (Consejo de Agricultura Ecológica de Murcia), 2019. Murcia Region Database. (accessed 21 May 2019). http://www.caermurcia.com.

Calatrava, J., Arcas, N., Martinez, I., 2006. Plan Estratégico del Sector Agroalimentario de la Región de Murcia. CARM, Murcia.

CARM, 2019. Precios en origen. Murcia Region Database. (accessed 21 May 2019). http://www.carm.es.

Clements, D.R., Weise, S.F., Brown, R., Stonehouse, D.P., Hume, D.J., Swanton, C.J., 1995. Energy analysis of tillage and herbicide inputs in alternative weed management systems. Agric. Ecosyst. Environ. 52, 119-128.
Clune, S., Crossin, E., Verghese, K., 2017. Systematic review of greenhouse gas emissions for different fresh food categories. J. Clean. Prod. 140, 766-783.

EC, 2019. (European Comission). (accessed 21 May 2019). https://ec.europa.eu/info/ news/preserving-our-soil-protect-our-food-2018-dec-05_en.

Eekhout, J.P.C., de Vente, J., 2019. The implications of bias correction methods and climate model ensembles on soil erosion projections under climate change. Earth Surf. Proc Land. 44, 1137-1147.

ESYRCE, 2018. (Encuesta de Superficies y Rendimientos de Cultivos). (accessed 13 February 2019). https://www.mapa.gob.es/es/estadistica/temas/estadisticasagrarias/agricultura/esyrce/.

EPC (European Parliament and Council), 2009. European Parliament. Directive 2009/28/ EC of European Parliament of the council of 23 April 2009 on the promotion of the use of energy from renewable sources and amending and subsequently repealing directives 2001/77/EC and 2003/30/EC. Official Journal of the European Union 2009.

FAO, 2019. Factors Influencing the Adoption of Conservation Agriculture. (accessed 17 May 2019). http://www.fao.org/3/y2781e/y2781e04.htm.

Garcia, J., Romero, P., Botia, P., Garcia, F., 2004. Cost-benefit analysis of almond orchard under regulated deficit (RDI) in SE Spain. Span. J. Agric. Res. 2, 157-166.

Gómez, J.A., Guzmán, M.G., Giráldez, J.V., Fereres, E., 2009. The influence of cover crops and tillage on water and sediment yield, and on nutrient, and organic matter losses in an olive orchard on a sandy loam soil. Soil Tillage Res. 106, 137-144.

Govaerts, B., Verhulst, N., Castellanos-Navarrete, A., Sayre, K.D., Dixon, J., Dendooven, L., 2009. Conservation agriculture and soil carbon sequestration: between myth and farmer reality. Crit. Rev. Plant Sci. 28 (3), 97-122.

Guardia, G., Tellez-Rio, A., García-Marco, S., Martin-Lammerding, D., Tenorio, J.L., Ibáñez, M.Á., Vallejo, A., 2016. Effect of tillage and crop (cereal versus legume) on greenhouse gas emissions and Global Warming Potential in a non-irrigated Mediterranean field. Agric. Ecosyst. Environ. 221, 187-197.

Hernánz, J.L., Giron, V.S., Cerisola, C., 1995. Long term energy use and economic valuation of three tillage systems for cereal and legume production in central Spain. Soil Tillage Res. 35 (4), 183-198.

Holland, J.M., 2004. The environmental consequences of adopting conservation tillage in Europe: reviewing the evidence. Agric. Ecosyst. Environ. 103, 1-25.

IPCC, 2006. Guidelines for national greenhouse gas inventories. In: HAS, Eggleston, Biennia, L., Miwa, K., Negara, T., Tanabe, K. (Eds.), Prepared by National Greenhouse Gas Inventories Programme. IGES. Eggleston Published, Japan.

ISO, 2006. 14040: Environmental Management - Life Cycle Assessment - Principles and Framework, 14044: Environmental Management - Life Cycle Assessment Requirements and Guidelines. International Organization for Standardization (ISO), Geneva.

MAGRAMA, 2015. Resultados Técnico-económicos de Frutales 2014, Subdirección General de Análisis, Prospectiva y Coordinación, Subsecretaría. Ministerio de Agricultura, Alimentación y Medio Ambiente.

Márquez, L., 2004. Maquinaria Agrícola, B\&H Editores S.L. Madrid.

Martínez-Mena, M., López, J., Almagro, M., Boix-Fayos, C., Albaladejo, J., 2008. Effect of water erosion and cultivation on the soil carbon stock in a semiarid area of South-East Spain. Soil Tillage Res. 99, 119-129.

Martínez-Mena, M., Garcia-Franco, N., Almagro, M., Ruiz-Navarro, A., Albaladejo, J., de Aguilar, J.M., Gonzalez, D., Querejeta, J.I., 2013. Decreased foliar nitrogen and crop yield in organic rainfed almond trees during transition from reduced tillage to no tillage in a dryland farming system. Eur. J. Agron. 49, 149-157.

Martínez-Mena, M., Carrillo-López, E., Boix-Fayos, C., Almagro, M., García Franco, N., Díaz Pereira, E., Montoya, I., de Vente, J., 2019a. Long-term effectiveness of Sustainable Land Management practices to control runoff, soil erosion, and nutrient loss and the role of rainfall intensity in Mediterranean rainfed agroecosystems. Catena (in press).

Martínez-Mena, M., Perez, M., Almagro, M., Garcia-Franco, N., Díaz-Pereira, E., 2019b. Long-Term Impacts of Sustainable Management Practices on Soil Properties and Crop Yields in Rainfed Mediterranean Almond Agroecosystems. submitted.

Marvinney, E., Kendall, A., Brodt, S., 2015. Life cycle-based assessment of energy use and greenhouse gas emissions in almond production, part II: uncertainty analysis through sensitivity analysis and scenario testing. J. Ind. Ecol. 19 (6), 1019-1029.

Miserque, O., Tissot, S., Bruart, J., 1997. Indicateur des Performances et Coûts d'utilisation des Machines Agricoles [Indicator of Agricultural Equipment Performance and Utilization Costs]. Centre de Recherches Agronomiques. C.E.M.A.G, Gembloux (Belgium)

Nemecek, T., Heil, A., Huguenin, O., Meier, S., Erzinger, S., Blaser, S., et al., 2000. Life cycle inventories of agricultural production systems. Final Report Ecoinvent 15, $145-146$.

Nemecek, T., Weiler, K., Plassmann, K., Schnetzer, J., Gaillard, G., Jefferies, G., GarcíaSuárez, T., King, H., Milà, L., 2012. Estimation of the variability in global warming potential of worldwide crop production using a modular extrapolation approach. J. Clean. Prod. 31, 106-117.

Myhre, G., Shindell, D., Bréon, F.M., Collins, W., Fuglestvedt, J., Huang, J., et al., 2013. Anthropogenic and natural radiative forcing. In: Stocker, T.F., Qin, D., Plattner, G.K., Tignor, M., Allen, S.K., Boschung, J. (Eds.), Climate Change 2013: The Physical Science Basis. Contribution of Working Group I to the Fifth Assessment Report of the Intergovernmental Panel on Climate Change. Cambridge University Press, Cambridge, UK, New York, NY, USA, pp. 659-740.

Page, G., Kelly, T., Minor, M., Cameron, E., 2011. Modeling carbon footprints of organic orchard production systems to address carbon trading: an approach based on life cycle assessment. HortScience 46 (2), 324-327.

Pre Consultants, 2019. SimaPro. The Netherlands. Retrieved from http://www.presustainability.com/SimaPro. (accessed 16 September 2018).

Ramos, M.E., Benítez, E., García, P.A., Robles, A.B., 2009. Cover crops under different 
managements vs. Frequent tillage in almond orchards in semiarid conditions: effects on soil quality. Agric., Ecosyst. Environ., Appl. Soil Ecol. 44, 6-14.

Sastre, C.M., Maletta, E., González-Arechavala, Y., Ciria, P., Santos-Montes, A., del Val, A., Pérez, P., Carrasco, J., 2014. Centralised electricity production from winter cereals biomass grown under central-northern Spain conditions: global warming and energy yield assessments. Appl. Energy 114, 737-748.

SIAM, 2019. (Servicio de Información Agraria de Murcia). (accessed 12 December 2018). http://siam.imida.es/.

Towery, D., 1998. No-till's impact on water quality. 1998. In: Proceedings of the Sixth Argentine National Congress of Direct Drilling Mar de Plata, Argentina, AAPRESID, Pp. 17-26.

UNEP-UNDP-UNCCD, 2008. Technical Note for Discussion at CRIC 7. (accessed 21 May 2019). http://www.archive.org/details/carbonindrylands08unep.

Uri, N.D., Atwood, J.D., Sanabria, J., 1998. The environmental benefits and costs of conservation tillage. Sci. Total Environ. 216, 13-32.

Velázquez-Martí, B., Fernández-González, E., López-Cortes, I., Salazar-Hernández, D.M., 2011. Quantification of the residual biomass obtained from pruning of trees in Mediterranean almond groves. Renew. Energy 36, 621-626.
Van Leeuwen, C.C.E., Cammeraat, E.L.H., de Vente, J., Boix-Fayos, C., 2019. The evolution of soil conservation policies targeting land abandonment and soil erosion in Spain: a review. Land Use Policy 83, 174-186.

Venkat, K., 2012. Comparison of twelve organic and conventional farming systems: a life cycle greenhouse gas emissions perspective. J. Sustain. Agric. 36 (6), 620-649.

West, T.O., Marland, G., 2002. A synthesis of carbon sequestration, carbon emissions and net carbon flux in agriculture: comparing tillage practices in the United States. Agric. Ecosyst. Environ. 91, 217-232.

Zaher, U., Stöckle, C., Painter, K., Higgins, S., 2013. Life cycle assessment of the potential carbon credit from no- and reduced-tillage winter wheat-based cropping systems in Eastern Washington State. Agric. Syst. 122, 73-78.

Tuomisto, H., Hodge, I., Riordan, P., Macdonald, D., 2012. Comparing global warming potential, energy use and land use of organic, conventional and integrated winter wheat production. Ann. Appl. Biol. 161, 116-126. https://doi.org/10.1111/j.17447348.2012.00555.x.

Van den Putte, A., Govers, G., Diels, J., Gillijns, K., Demuzere, M., 2010. Assessing the effect of soil tillage on crop growth: a meta-regression analysis on European crop yields under conservation agriculture. Eur. J. Agron. 33, 231-241. 